Vol.7, No.1 (2020)

Hal : $28-33$

\title{
KREATIVITAS GURU DALAM MENUMBUHKAN MINAT BELAJAR SISWA DI MIN 8 ACEH BARAT
}

\author{
M. REZKI ANDHIKA ${ }^{1}$ ), CUT NELI WAHYUNI²) \\ ${ }^{1,2}$ ) STAIN Teungku Dirundeng Meulaboh, Jalan SM Raja, Desa Gampa, Kec. Johan Pahlawan, Meulaboh. \\ "Email : rezki.andhika@gmail.com
}

\begin{abstract}
Abstrak
Perkembangan Pendidikan Dasar di Indonesia masih banyak yang perlu dibenahi, seperti kekurangan jumlah dan kualitas Guru. Peran dan fungsi guru dalam mencerdaskan siswa sangat dominan dan menentukan, serta mempunyai pengaruh yang sangat besar terhadap perkembangan dan pertumbuhan kualitas pendidikan.Pendidikan yang berkualitas juga ditentukan oleh kreativitas guru untuk meningkatkan minat belajar siswa. Karena siswa terkadang bosan dan jenuh dengan pelajaran yang tetap dan selalu sama.Penelitian ini bertujuan untuk mengetahui apa saja bentuk kreativitas gurudi MIN 8 Aceh Barat dalam menumbuhkan minat belajar siswa. Penelitian ini merupakan penelitian lapangan dengan menggunakan metode kualitatif. Data dikumpulkan melalui observasi, wawancara dan dokumentasi. Hasil penelitian menunjukkan kreatifitas gurudi MIN 8 Aceh Barat dalam menumbuhkan minat belajar siswa terdiri dari: Penggunaan media belajar yang kreatif seperti media audio, audio visual, media kartu kata dan media gambar, Penggunaan strategi mengajar kreatif dan bervariasi seperti diskusi, kelompok, ceramah, tanya jawab, penugasan dan strategi Reading Aloud, Pengelolaan kelas yang kreatif seperti formasi leter-U dan berkelompok. Sementara penerapan kreatifitas guru diterima dengan baik. Dengan kata lain Secara keseluruhan penerapan kreatifitas guru mendapatkan respon dari siswa, dan menumbuhkan minat belajar siswa.
\end{abstract}

Kata Kunci : Kreativitas Guru, Minat Belajar Siswa, Pendidikan Dasar

\section{PENDAHULUAN}

Di Indonesia Sekolah Dasar (SD) adalah salah satu bentuk pendidikan formal yang menyelenggarakan pendidikan umum pada jenjang pendidikan dasar. Selain itu juga Madrasah Ibtidaiyah (MI), adalah salah satu bentuk satuan pendidikan formal dalam binaan Menteri Agama yang menyelenggarakan pendidikan umum dengan kekhasan Agama Islam pada jenjang pendidikan dasar.

Perkembangan Pendidikan Dasar baik SD (sekolah dasar) maupun MI (Madhrasah Ibtidaiyah) di Indonesia masih banyak yang perlu dibenahi karena masalah-masalah yang masih banyak muncul. Pemerintah harus memperhatikan hingga hal-hal yang detail seperti sarana dan prasarana yang kurang atau kekurangan jumlah dan kualitas Guru. Tidak dapat dipungkiri peran serta fungsi guru dalam mencerdaskan anak didiksangat dominan dan menentukan, serta mempunyai pengaruh yang sangat besar terhadap perkembangan dan pertumbuhan kualitas pendidikan.

Pendidikan yang berkualitas juga salah satunya ditentukan oleh kreativitas guru untuk menemukan ide-ide baru bagi pemecahan suatu masalah yang berkaitan dengan ilmu pengetahuan serta tingkah laku dari peserta didik. Karena pada saat ini banyak siswa yang terkadang bosan dan jenuh dengan pelajaran yang tetap dan selalu sama.Fase perkembangan minat berlangsung secara bertingkat dan mengikuti pola perkembangan individu serta kematangan individu itu sendiri karenan semakin matang maka minat juga akan semakin kuat dan terfokus pada objek tertentu pada awalnya, minat terpusat pada diri sendiri (hal-hal yang menjadi kepunyaan) kemudian terpusat pada orang lain (pada objek yang ada pada lingkungan). (Susanto, Ahmad, 2013:64.). 
Kecenderungan siswa dalam memilih atau menekuni suatu mata pelajaran secara intensif dibanding dengan mata pelajaran lain pada dasarnya dipengaruhi oleh minat siswaitu sendiri. Namun, minat seorang siswa juga banyak dikontrubusi oleh pola dan kebiasaan yang mereka alami. Pola dan kebiasaan tersebut bisa berasal dari proses dalam belajar mengajar melalui penyampaian materi belajar oleh guru. Artinya, bisa saja seorang siswa berminat terhadap mata pelajaran yang sebelumnya tidak ia minati, namun karena pengaruh yang diberikan oleh guru akhirnya berminat, karena dari kebiasaan itu siswa cenderung meniru, yang akhirnya menjadi kesenangan yang bersifat tetap yaitu minat.

Sebagai contoh minat siswa terhadap mata pelajaran Matematika misalnya, pada dasarnya banyak yang memengaruhinya. Salah satunya guru mengajarkan trik dalam perkalian yang membuat siswa menjadi cepat dalam menyelesaikan soal perkalian. Begitu juga dengan mata pelajaran yang lainnya, yang membuat siswa menjadi berminat yang dipengaruhi oleh seorang guru. Suasana seperti inilah yang akan memudahkan materi pelajaran masuk dalam fikiran dan pemahaman siswa. Ini terjadi karena adanya minat. Minat demikianlah yang seyogyanya dimiliki oleh seorang siswa, yang dengan sendirinya mau memusatkan secara intensif pada suatu mata pelajaran.

Dengan demikian seorang guru dituntut untuk lebih kreativ dalam mengolah proses pembelajaran menjadi sesuatu yang unik dan menarik. Kreativitas mengajar didefinisikan sebagai suatu kualitas dimana guru harus mengembangkan ide-ide yang baru dan imajinatif dalam mengajar. Oleh karena itu, suatu respon kreatif dalam mengajar bisa berupa pengelolaan kelas yang baik yang dapat membuat suasana belajar menjadi kondusif, penggunaan media belajar yang menarik, dan variasi dalam gaya mengajar.

\section{METODE PENELITIAN}

\section{Tempat Peneitian}

Penelitian ini dilakukan di MIN 8 Aceh Barat yang terletak di jalan Cot Lawang, Gampong Drien Rampak, Kecamatan Johan Pahlawan, Kabupaten Aceh Barat.

\section{Jenis Penelitian}

Penelitian ini merupakan penelitian lapangan (field research) yang bermaksud mempelajari secara intensif tentang latar belakang keadaan sekarang dan interaksi suatu sosial, individu, kelompok, lembaga, dan masyarakat. Dalam hal ini, penelitian yang digunakan oleh peneliti yaitu lebih kepada penelitian yang bersifat deskriptif (descriptive research) dalam artian suatu penelitian yang lebih memprioritaskan pada gambaran kejadian-kejadian atau peristiwa pembelajaran yang kreatif yang dilakukan oleh semua guru di MIN 8 Aceh Barat khususnya guru yang mengajar di kelas IV.

\section{Sumber Data}

Penelitian ini bertujuan untuk mengetahui bentuk dan penerapan kreativitas guru dalam pelaksanaan pembelajaran, maka subjek penelitian yang adalah:

\section{Guru}

Guru yang dimaksud adalah guru yang mengajar di kelas IV sebagai subjek yang memiliki dan menerapkan kreativitasnya dalam pelaksanaan pembelajaran di MIN 8 Aceh Barat.

\section{Siswa}

Siswa yang dimaksud adalah siswa kelas IV MIN 8 Aceh Barat sebagai subjek penerima rangsangan dari kreativitas seorang guru dalam pelaksanaan pembelajaran

\section{Kepala Madrasah}

Kepala sekolah yang dimaksud adalah kepala sekolah MIN 8 Aceh Barat yang bernama Nurdin, S.Pd.I., sebagai subjek pemberi informasi atau data yang terkait dengan kreativitas guru MIN 8 Aceh Barat dan juga sebagai penanggung jawab dalam penentuan sistem pelaksanaan pembelajaran. 


\section{HASIL DAN PEMBAHASAN}

\section{Kreativitas Guru}

Yang dimaksud kreativitas adalahkemampuan seseorang untuk melahirkan sesuatu yang baru, baik berupa gagasan maupun karya nyata, yang relatif berbeda dengan yang sudah ada sebelumnya.(Narwanti, Sri. 2011:4)

Kreativitas merupakan kemampuan yang dimiliki seseorang untuk menemukan sesuatu hal baru, cara-cara baru, model baru yang berguna bagi dirinya dan bagi masyarakat. Hal baru itu tidak perlu selalu sesuatu yang sama sekali tidak pernah ada sebelumnya, unsur-unsurnya mungkin telah ada sebelumnya, tetapi individu menemukan kombinasi baru, hubungan baru, konstruk baru yang memiliki kualitas yang berbeda dengan keadaan sebelumnya(Sukmadinata, Nana Syaodih. 2004:104).

Guru merupakan suatu profesi, yang berarti suatu jabatan yang memerlukan keahlian khusus sebagai guru dan tidak dilakukan oleh sembarangan orang di luar bidang pendidikan. Kreativitasinimerupakan upayamembangunberbagaiterobosanyangmemungkinkanbagipemberdayaandanpenguatan bagipengembanganbakat yangtelahtergali.Disinilaharti danmaknapenting kreativitasuntuk menunjang kesuksesan(Naim, Ngainum. 2011: 244).

Guru sebagai pendidik atau pengajar merupakan penentu kesuksesan dalam pendidikan. Oleh sebab itu, guru dituntut untuk mengembangkan kreativitasnya dalam proses belajar mengajar. Guru yang kreatif selalu mencari cara bagaimana agar proses mencapai hasil sesuai dengan tujuan, serta berupaya menyesuaikan pola-pola tingkah lakunya dalam mengajar dengan tuntutan pencapaian tujuan, dengan mengembangkan faktor situasi kondisi belajar siswa. Kreativitas ini memungkinkan guru yang bersangkutan menemukan bentuk mengajar yang sesuai, terutama dalam memberi bimbingan, dorongan, dan arahan agar siswa dapat belajar secara efektif.

\section{Ciri-Ciri Kreativitas Guru}

Untuk mengembangkan potensi-potensi yang ada pada diri anak, dibutuhkan guru yang kreatif. Adapun ciri-ciri guru yang kreatif adalah sebagai berikut:

1. Mampu mengekspos siswa pada hal-hal yang bisa membantu mereka dalam belajar.

2. Mampu melibatkan siswa dalam segala aktivitas pembelajaran.

3. Mampu memberikan motivasi kepada siswa

4. Mampu mengembangkan strategi pembelajaran.

5. Mampu menciptakan pembelajaran yang joyful dan meaningful.

6. Mampu berimprovisasi dalam proses pembelajaran.

7. Mampu membuat dan mengembangkan media pembelajaran yang menarik dan aplikatif.

8. Mampu membuat dan mengembangkan bahan ajar yang variatif.

9. Mampu menghasilkan inovasi-inovasi baru dalam pembelajaran(Anomim, 2012: 1).

Adapun aspek-aspek dari kreativitas antara lain adalah sebagai berikut: person, process, press, product. Person yang berarti kepribadian yang dimiliki oleh seorang guru, process maksudnya adalah berfikir kreatif (luwes, lancar, elaborative), press maksudnya adalah dorongan seorang guru untuk melakukan kegiatan kreatif serta product sebagai hasil dari buah kreativitas guru yang diterapkan dalam pembelajaran (Hamzah B. Uno dan Nurdin Muhammad, 2012: 15).

Kreativitas mengajar guru merupakan upaya guru dalam memunculkan sesuatu yang baru ataupun berupa kombinasi-kombinasi yang berbeda dengan sebelumnya dalam hal mengajar. Kreativitas guru bisa berupa penggunaan media dalam mengajar, penggunaan variasi dalam gaya mengajar, dan kemampuan dalam pengelolaan kelas sehingga dapat menciptakan kondisi belajar yang kondusif.

Guru yang kreatif adalah guru yang mampu mengaktualisasikan dan mengekpresikan secara optimal segala kemampuan yang ia miliki dalam rangka membina dan mendidik anak didik dengan baik. Seorang guru yang kreatif akan memiliki sikap kepekaan, inisiatif, cara baru dalam mengajar, kepemimpinan serta tanggung jawab yang tinggi dalam pekerjaan dan tugasnya sebagai seorang pendidik. Dengan kata lain guru yang kreatif adalah guru yang kaya akan ide-ide dan menerapkannya dalam bentuk nyata, yang dalam realitanya kreatifitas guru mampu mengatasi kebosanan pada siswa. 
Jadi dapat disimpulkan bahwa yang dimaksud dengan kreativitas guru dalam proses pembelajaran, yaitu suatu kemampuan yang dimiliki oleh seorang guru dalam mengelola kelas disaat proses belajar mengajar, penggunaan media belajar yang menarik sehingga dapat merangsang minat belajar siswa, dan mampu membuat gaya belajar yang bervariasi dalam pembelajaran, sehingga dapat mengolah proses pembelajaran menjadi suatu pembelajaran yang menarik yang belum pernah ada sebelumnya.

Oleh karena itu dapat menyimpulkan bahwa suatu respon kreatif dalam mengajar bisa berupa pengelolaan kelas yang baik yang dapat membuat susana belajar menjadi kondusif, penggunaan media belajar yang menarik dan variasi dalam gaya mengajar. Kreativitas mengajar terkait dengan kemampuan mengajar untuk menciptakan suasana yang membuat siswa merasa nyaman dan tertantang dalam belajar dengan membuat kombinasi-kombinasi baru dan memungkinkan untuk menemukan alternative jawaban terhadap suatu permasalahan dimana hal tersebut dapat menjadi karya yang orisinil yang sebelumnya belum ada.

Berdasarkan hasil penelitian tentang Kreativitas guru dalam meningkatkan minat belajar siswa min 8 aceh barat, menunjukkan bentuk kreativitas guru min 8 aceh barat adalah; Pertama, penggunaan media belajar yang dapat menarik perhatian siswa. Kedua, berupa variasi dalam penyampaian bahan ajar sehingga menjadi proses pembalajaran yang menyenangkan. Ketiga, penguasaan kelas yang baik sehingga menghasilkan suasana lingkungan balajar yang kondusif. Adapun deskripsi dari hasil penelitian tersebut adalah sebagai berikut :

\section{Penggunaan Media Belajar}

Proses pembelajaran akan berhasil jika siswa turut aktif dalam pembelajaran tersebut. Oleh karena itu diperlukan berbagai fasilitas yang digunakan guru sebagai media pembelajaran agar dapat lebih mengoptimalkan hasil belajar. Gurudi MIN 8 Aceh Barat dalam penggunaan media belajar tergolong inovatif dan kreatif. Guru menggunakan media itu sesuai dengan materi yang diajarkan. Diantara media belajar inovatif dan kreatif yang digunakan adalah media kartu kata, gambar poster, peta,rekaman suara, video dan media lainnya yang disesuaikan dengan materi

pembelajaran

Tabel : Penggunaan Media Belajar Oleh Guru MIN 8 Aceh Barat Sesuai Dengan Materi yang Diajarkan

\begin{tabular}{clll}
\hline No & Media belajar & Mata Pelajaran & Materi Pelajaran \\
\hline 1 & Video film kartun & SKI (sejarah kebudayaan islam) & Sejarah Nabi Ibrahim, a.s. \\
2 & Kartu Kata & B. Inggris & Menyusun Kalimat \\
3 & Gambar Poster & Al-qur'an Hadist & Makhrajul Huruf \\
4 & Rekaman Suara & Al-qur'an Hadist & Bacaan Makhrajul Huruf \\
\hline
\end{tabular}

Dapat simpulkan bahwa beberapa guru MIN 8 Aceh Barat telah tepat dan kreatif dalam menggunakan media belajar pada proses pembelajaran. Penggunaan media Belajar yang kreatif menjadi salah satu penggerak penting dalam menumbuhkan minat belajar siswa, karena media belajar adalah bagian tidak terpisahkan dalam proses pembelajaran.

\section{Metode Pembajaran}

Setelah penggunaan media belajar, guru MIN 8 Aceh Barat juga berinovasi dengan variasi metode pembelajaran yang sesuai dengan materi pelajaran, yangdiharapkan dapatmeningkatkan minat belajar serta membuat siswa memiliki pemahaman yang lebih mendalam tentang materi yang disampaikan. Siswa tidak hanya memahami 
dan menghafal materi saja, tapi juga akan mampu mengaplikasikan pengetahuannya pada kehidupan nyata. Melalui hal tersebut siswa akan memiliki pengalaman belajar yang lebih bermakna.

Dalam hal menggunakan berbagai variasi metode pembelajaran guru MIN 8 Aceh Barat sudah tergolong inofatif. Metode pembelajaran yang digunakan adalah metode pembelajaran yang sesuai dengan materi pelajaran yang akan disampaikan kepada siswa. Jon Karnaidi (Guru Pendidikan Agama Islam di MIN 8 Aceh Barat)dalam wawancara mengatakan bahwa "menggunakan hanya satu metode mengajar akan membuat siswa bosan, jadi dalam mengajar harus diterapkan beberapa variasi metode mengajar seperti metode mengajar diskusi, kerja kelompok, ceramah, tanya jawab, penugasan, dan metode pembelajaran lainnya yang akan kita sesuai dengan materi yang akan diberikan. Penerapannya bisa bergantian atau diracik sedemikian rupa dengan menggabungkan dua atau lebih metode pembelajaran".

Sebagai contoh, metode diskusi yang dimaksud bukan metode diskusi biasa, namun sudah di modifikasi sedemikan rupa. Metode mengajar diskusi ini menjadi salah satu kunci penting agar siswa saling berinteraksi mengenai topik yang dibahas adalah cara penugasan kelompok. Guru memberikan siswa satu tugas yang harus dikerjakan secara bersama-sama dan guru pula yang menentukan siapa saja yang harus berada dalam satu kelompok dengan memperhatikan siswa yang rajin, pintar, kurang menonjol, pendiam, harus dicampur. Melalui kerjasama, siswa akan saling merasa ada ketergantungan satu sama lain. Mereka harus membangun kepercayaan karena mau tidak mau semua tugas harus dikerjakan secara bersama-sama jika tidak mereka akan rugi bersama dan sudah pasti hal tersebut akan dihindari. Siswa akan berupaya semaksimal mungkin untuk mengerjakan tugas dengan berdiskusi secara intensif.

Selain metode diskusi guru juga menggunakan strategi pembelajaran ceramah untuk memberikan jeda waktu dan membangun konsep dasar agar siswa siap untuk menerima pelajaran. Dengan metode ini dapat mewujudkan proses belajar mengajar yang interaktif di dalam kelas. Menggunakan beberapa media pembelajaran seperti menggunakan laptop untuk menampilkan presentasi dalam bentuk power point atau juga bisa menampilkan berbagai film atau video dan lainnya untuk menambah daya tarik ceramah. Dapat juga memperagakan berbagai macam gerakkan shalat disaat memberi materi prakter shalat. Cara lain dengan memberi catatan tertulis yang terkait materi yang dibahas agar siswa dapat lebih fokus.

Selanjutnya, membaca nyaring atau reading aloaud merupakan bentuk strategi membaca suatu teks dengan keras yang dapat membantu memfokuskan perhatian secara mental menimbulkan pertanyaan-pertanyaan dan merancang diskusi. Metode ini mempunyai efek pada memusatkan perhatian dan membuat suatu kelompok yang kohesif. Metode kreatif ini dapat guru terapkan dalam proses pembelajaran yang sesuai dengan materi "cara membaca nyaring suatu pengumuman dengan intonasi yang tetap" pada mata pelajaran Bahasa Indonesia. Hal ini mengingat agar dapat membantu siswa untuk berkonsentrasi, mengajukan pertanyaan dan menggugah sebuah diskusi, yang pada akhirnya memberi pemahaman yang mendalam pada diri siswa.

Jadi dapat disimpulkan bahwa guru selalu memberikan cara yang berbeda dalam penyampaian pelajaran. Siswa akan terbantu mengekspresikan berbagai perasaan mereka saat guru menggunakan beragam metode mengajar. Mengekpresikan perasaan akan dapat siswa lakukan dengan berbagai cara, sebagai dampak dari penggunaan metode mengajar yang bervariasi. Yangakan membuat siswa mengikuti pembelajaran dengan sukarela dan bersemangat untuk berpatisipasi aktif. Mereka akan berpikir secara mandiri, dan secara tanpa sadar mereka telah tenggelam dan terlibat aktif dalam pembelajaran yang disampaikan guru.

\section{Pengelolaan Iklim Kelas.}

Dalam penyampaianpelajaran, guru juga dituntut mampu mengelola iklim kelas dengan baik. Suatu kondisi kelas yang kondusif yang merupakan persyaratan untuk terjadinya proses pembelajaran yang efektif, oleh karena itu guru perlu menguasai pengelolaan iklim kelas agar dapat menarik minat siswa dalam belajar.

Guru MIN 8 Aceh Barat dalam penataan ruang kelas tergolong inofatif. Hampir semua kelas yang ada di MIN 8 Aceh Barat ditata dengan bentuk-bentuk yang berbeda. Misalnya meja kursi belajar siswa tidak hanya disusun berbaris-baris menghadap kepapan tulis, namun ada yang berbentuk formasi liter $\mathrm{U}$, ada juga yang disusun berkelompok-kelompok. Hal ini dapat berubah pada setiap minggunya. Sehingga siswa tidak hanya duduk pada satu tempat tertentu dan berpasangan dengan teman tertentu selama satu semester. Hal ini membuat siswa dapat 
berinteraksi dengan baik dan bertukar pikiran terhadap teman sekelasnya. Sehingga siswa tidak merasa canggung atau malu dalam menggekspesikan diri ketika mengikuti proses pembelajaran.

Untuk memberi suasana yang nyaman, dan menghindari timbulnya semeraut dan kegaduhan siswa, sebelum memulai pelajaran guru mengkondisikan kelas agar menciptakan lingkungan belajar yang kondusif.Guru melakukan penataan kelas sebelum memulai mengajar, memerintahkan siswa untuk tertip, menegur siswa apabila siswanya ribut, dan apabila pembelajarannya sudah dimulai, siswa tidak diizinkan oleh guru untuk keluar masuk kelas bila dianggap tidak penting.

Selanjutnya penggololaan kelas sangat penting dikarenakan bila kondisi kelas kotor, pandangan siswa terhalang, kondisi kelas gelap atau kurang cahaya dan lain-lain, akan berakibat siswa yang awalnya memiliki minat mengikuti pelajaran menjadi hilang ketertarikan terhadap pelajaran. Begitu juga posisi duduk siswa, guru dapat mengganti teman duduk siswa bila dianggap perlu. Hal ini dapat guru lakukan untuk menghindari siswa mendapatkan gangguan dari teman sebangkunya.

Dapat disimpulkan bahwa pengololaan kelas yang baik merupakan bagian kelas terpenting dari kegiatan pembelajaran, karena dalam pengelolaan kelas yang baik dapat mempengaruhi siswa dalam keefektifan penyampain materi.

\section{Kesimpulan}

Berdasarkan analisis dan pembahasan yang telah dipaparkan oleh peneliti di atas sebelumnya, maka kreatifitas guru dalam menumbuhkan minat belajar siswa di MIN 8 Aceh Barat dapat disimpulkan bahwa: Guru memiliki beberapa bentuk kreatifitas pada tiga tempat dalam menumbuhkan minat belajar siswa, antara lain:

1. Penggunaan media belajar yang kreatif seperti media audio, audio visual, media kartu kata dan media gambar

2. Penggunaan strategi mengajar kreatif dan bervariasi seperti diskusi, kelompok, ceramah, tanya jawab, penugasan dan strategi Reading Aloud.

3. Pengelolaan kelas yang kreatif seperti formasi liter-U dan berkelompok.

Selanjutnya, beberapa bentuk kreatifitas guru tersebut, diterapkan dalam menumbuhkan minat belajar pada proses belajar mengajar. Dilihat dari sisi penerapan kreativitas guru dalam menumbuhkan minat belajar siswa di MIN 8 Aceh Barat, guru di sekolah tersebut telah menerapkan bentuk kreatifitasnya pada tiga tempat tersebut diterima dengan baik dan sesuai. Secara keseluruhan penerapan kreatifitas guru mendapatkan respon dari siswa, dan menumbuhkan minat belajar siswa.

Meskipun hasil penelitian ini telah membuktikan bahwa usaha guru dalam menumbuhkan minat belajar siswa di MIN 8 Aceh Barat bisa dikatakan sudah baik, akan tetapi guru diharapkan bisa terus aktif dan kreatif dalam penggunaa gaya mengajar yang bervariasi dalam memberikan pembelajaran kepada siswa, penggunaan alat peraga karena akan memudahkan guru dalam menyampaikan materi pembelajaran dan siswa juga akan tertarik dengan pembelajaran yang diajarkan oleh guru.

\section{DAFTAR PUSTAKA}

Ahmad Susanto, Teori Belajar \& Pembelajaran di Sekolah (Jakarta: PT Fajar Interpratama Mandiri, 2013), Cet. Ke I.

Anomim, Ciri-Ciri Guru Kreatif Yang Profesional, (Bandung: PT. Remaja Rosdakarya, 2012).

Hamzah B. Uno \& Nurdin Muhammad, Belajar Dengan Pendekatan PALKEM (Jakarta: Bumi Aksara, 2011).

Nana Syaodih Sukmadinata, Landasan Psikologi Proses Pendidikan (Bandung: Remaja Rosdakarya, 2004), cet ke II.

Ngainum Naim, Rekonstruksi Pendidikan Nasional Membangun Paradigma yang Mencerahkan, (Yogyakarta: Teras, 2009).

Sri Narwanti, Creative Learning Kiat Menjadi Guru Kreatif dan Favorit (Yogyakarta: Familia, 2011) 
ISSN : 2303-355X 